\title{
The Hungarian peach production risks
}

\author{
Persely, Sz. \\ University of Debrecen, Centre for Agricultural Sciences and Engineering, Department of Economic Analysis \\ and Statistics, H-4032 Debrecen, 138 Böszörményi, Hungary
}

Summary: Hungary possesses very good agroecological conditions even in a European comparison. Agriculture and food production is highly important despite its decreasing relative economic significance, since providing high quality and affordable food for the population is a basic social necessity and one of the decisive factors in quality of life. The development of vegetable and fruit production is of great importance both from a healthy nutrition as well as from a comparative advantage (cheap labour, expertise, production traditions, favourable climate) point of view. Vegetable and fruit consumption per capita is lower than in developed countries, which is a decisive indicator of healthy nutrition, but improvement is continuous and desired. Appropriate quality and quantity in production is a requirement to meet customers' needs in a highly competitive market from one year to the next. Hungary can only be competitive if production results are improved while risks are reduced. Fruit production is a sector with high capital requirements, risk assessment is very important from a production, investment as well as from a national economy point of view. Our examinations will focus on production risk, which is present in the annual fluctuation of average yields, especially as a result of extreme weather factors.

Key words: peach, production, Hungary, risks

\section{Introduction}

Hungary lies on the northern border of economical peach production. Early spring and winter frosts represent the primary risk of production. This fruit can only be produced safely in areas with lower risk of frost, such as hilltops and hillsides. The frost tolerance of plant parts is a result of a long process. Peach sprouts and parts above ground are only significantly damaged below $-20{ }^{\circ} \mathrm{C}$ during deep dormancy. Warming up following deep dormancy results in accelerated vital processes. One or two week long warmer periods in January and February are common in Hungary during which plant parts lose their frost tolerance. If vegetation starts later, the risk of frost is lower (eg.: on the north, north west slopes and in the case of cold tolerant types). Parts above ground are damaged to some extent every year in Hungary due to winter cooling down. Due to early autumn (October, November) cooling down, the not ripened shoots or not yet acclimatised parts (ends of shoots) get frostbitten. Development of plant tissues is slow due to bad nutrient supply in the narrow branches therefore frostbite often occurs. Frost damage, which results in the significant loss of yield, usually occurs twice of four times over the course of ten years on production sites of the Hungarian plains. Damages to buds of peach types can reach $100 \%$ in certain years. Weather following frost damage, especially during flowering, strongly influences yield. Beneficial conditions for yield, such as average daily temperatures exceeding $10^{\circ} \mathrm{C}$ and dry, windless conditions, could result in outstanding yield quantities (20-30 t/ha) even for trees with 30-40\% damage, or a $50-80 \%$ frost damage can be followed by medium (10-15 t/ha) or good (15-20 t/ha) yields (Szabó et al., 2004). All these factors can also influence plant protection (Soltész \& Holb, 2007).

\section{Materials and methods}

Production risk is calculated by applying variance and relative deviation indicators. Technological development has to be taken into consideration in case of long time sequences and the trend effect has to be examined in the data sequences. Because of this, we began the evaluation with trend analysis and applied trend functions in the data sequences. The periodical development of a phenomenon is determined by the joint effect of several factors, resulting in the actual or experienced results. These results are the following:

- basic tendency or trend

- periodical fluctuation (within and beyond a year)

- random fluctuation (Ertsey, 1990).

The random effect can be defined numerically with the error of the trend function, the so-called residual deviation, which is in direct proportion to the degree of the risk.

The database for our examination was based on own data collection as well as on data provided by the HCSO. 


\section{Areas suitable for peach production in Hungary}

As it has been previously mentioned, Hungary lies on the northern border of peach production (between latitudes 46-48.), but still within the realistic zone of production, which means that necessary ecological conditions are not always provided and there are areas where economical peach production cannot be achieved (Timon, 2000).

The success of integrated peach production in Hungary depends primarily on the selection of cultivation site. This mediterranean species can only resist diseases and can be cultivated with less industrial materials (pest control, fertiliser) application, if it is cultivated in areas with the most suitable ecological conditions, especially in favourable locations and on soils. Selection of cultivation site is one of the most important questions of successful and profitable fruit production. The areas of peach cultivation are illustrated in figure 1 .

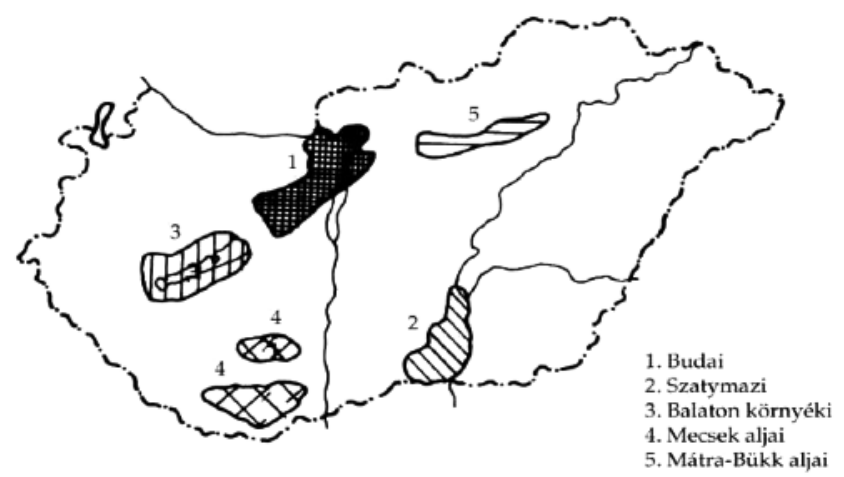

Source: Timon, 2000

Figure 1. Regions most suitable for peach production in Hungary

The most suitable peach production areas are the following (Figure 1):

- vicinity of Buda, the protected southern slopes of Pilis, Gerecse and Vértesalja (1. cultivation site)

- not low lying sand ridges of Szeged-Szatymaz area (2. cultivation site)

- Balaton area, both northern and southern hillsides (3. cultivation site)

- Mecsekalja, southern hillsides of Baranya and Tolna (4. cultivation site)

- Mátraalja, from Pásztó to Eger (5. cultivation site)

Our peach production gradually decreased following the peak of the 1970s and reached its lowest point in the 90s (Timon, 2000). The highest yield was achieved in 1972 (131 800 tonnes), and fluctuated between 42000 and 75000 tonnes in the 90s. The yield quantity of peach in Hungary between 1981 and 2005 can be seen in Figure 2.

The yield averages of peach production and its relative deviation in the counties covering the main cultivation regaions in Hungary are shown in Table 1. The average yields are the averages of yields in 2002, 2003, 2004 and 2005. As it can be seen in Table 1. Hungarian peach production is characterised by low production standard and significant differences can be detected among the various counties as well. The standard of production is highest in Veszprém county and lowest in Bács-Kiskun county. Production is the most unfavourable in Bács-Kiskun county, most favourable in Somogy county, where relative yield fluctuation is only $13.26 \%$. The abovementioned is illustrated in Figure 3.

Table 1. Average yield and relative deviation of main peach producing counties in 2002 and 2005

\begin{tabular}{|l|c|c|c|}
\hline \multicolumn{1}{|c|}{ County } & $\begin{array}{c}\text { Producing } \\
\text { region }\end{array}$ & $\begin{array}{c}\text { Yield avergae } \\
\mathrm{kg} / \mathrm{ha}\end{array}$ & $\begin{array}{c}\text { Relative } \\
\text { deviation } \\
\%\end{array}$ \\
\hline Somogy & 4. & 5957.5 & 13.26 \\
\hline Pest & 1. & 5292.5 & 16.42 \\
\hline Baranya & 4. & 5017.5 & 37.72 \\
\hline Veszprém & 3. & 7912.5 & 48.80 \\
\hline Heves & 5. & 7335.0 & 52.55 \\
\hline Fejér & 1. & 7455.0 & 65.07 \\
\hline Bács-Kiskun & 4. & 4517.5 & 67.86 \\
\hline
\end{tabular}

Source: own calculation based on HCSO data

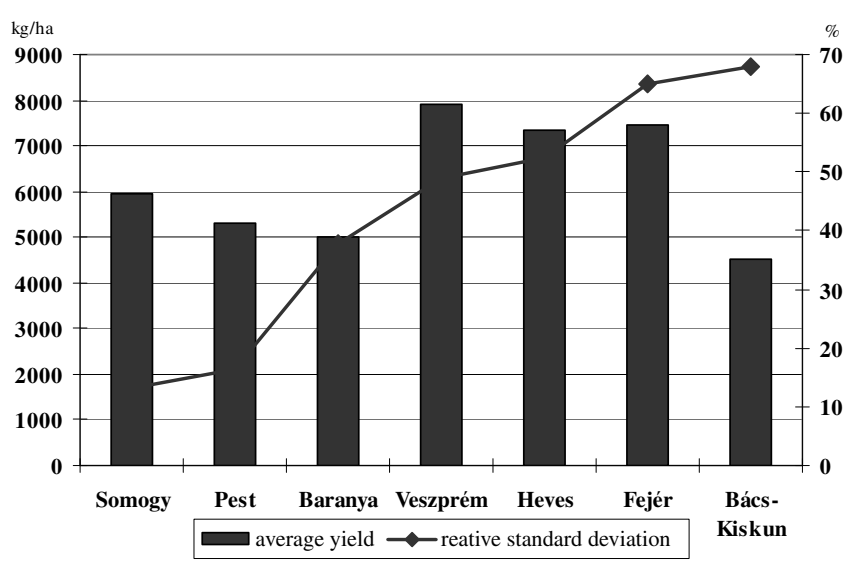

Source: own compilation

Figure 3. Yield average and relative deviation in different counties 
The size of peach cultivation area does not follow risk indicators. We can see in Figure 4, that cultivation area is the largest in Pest county in cultivation site 1., which is determined by relative low risk and proximity of the purchasing market. The second largest production area can be found in Bács-Kiskun county, where production risk is the highest (68\%), which means an extreme fluctuation of yields. This cultivation site located on a plain is traditionally a fruit, grapes and vegetable production area because of weak soil characteristics. Peach production is primarily present due to processing capacities in the proximity (fruit juice) and it is still competitive with other sectors within this region despite high risks.

The characteristics of three specific orchards are shown below in connection with the previously mentioned outstanding production regions.

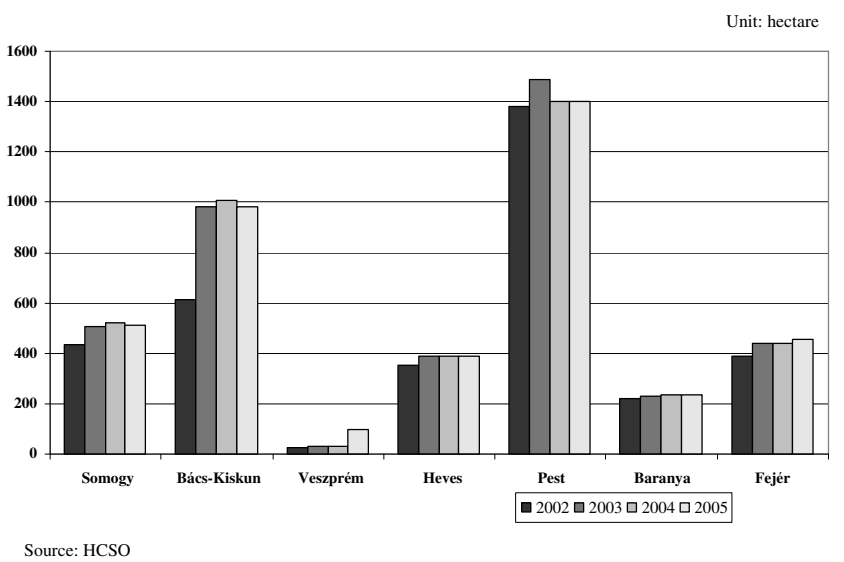

Figure 4. Production area of peach in the major producing counties of Hungary

\section{Siófok plantation}

The introduced peach plantation is old in the relatively low risk production area and, as it can be seen from Figure 5, yield averages strongly decreased in 1998-2007 and risk significantly exceeds the average of the cultivation site (32\%).

The characteristics of the plantation can be seen in Table 2 .

\section{Gyöngyös plantation}

The Gyöngyös plantation can be found in Heves county in the Mátra-Bükk foothill cultivation site. The yield average of this new, modern plantation is three times that of the previously mentioned plantation. Production risk is $37 \%$, which is significantly lower than the average of the production region. The characteristics of the plantation are shown in Table 3.

\section{Mezőnyárád plantation}

It is located on the edge of the Mátra-Bükk foothill cultivation area, the elevation does not reach the desired 300 meters above sea level, as it is only at 136 meters (Nyéki, 2004). 2007 was especially severe in agriculture. Significant ice and frost damage accompanied drought. The biggest damages were caused by winter and spring cooling offs, but the negative effects of high temperatures can also be detected (Szabó, 1997). On 22-23 April, 2007. and 2-3 May brought frost damages unparalleled for sixty years affecting almost the entire fruit production area of Hungary. The extent of

Table 2. Characteristics of the plantation in Siófok

\begin{tabular}{|l|c|}
\hline \multicolumn{1}{|c|}{ Type } & $\begin{array}{c}\text { Suncrest, Regina, Redhaven*, } \\
\text { Cardinal }\end{array}$ \\
\hline Year of plantation & 1975 \\
\hline Subject & bitter almond \\
\hline Crown shape & Fat cone \\
\hline Row distance and distance between trees & $6.5 * 4$ \\
\hline Size of plot (ha) & 35.93 \\
\hline Soil quality (AK) & 37 \\
\hline Irrigation & yes \\
\hline Method of irrigation & sprinkle \\
\hline Frequency of frost damage & no cases / 10 year \\
\hline Protection against frost & 3 cases / 10 years \\
\hline Frequency of frost damage & no \\
\hline Protection against frost & \\
\hline
\end{tabular}

Source: own compilation

Comment: *excellent frost tolerance

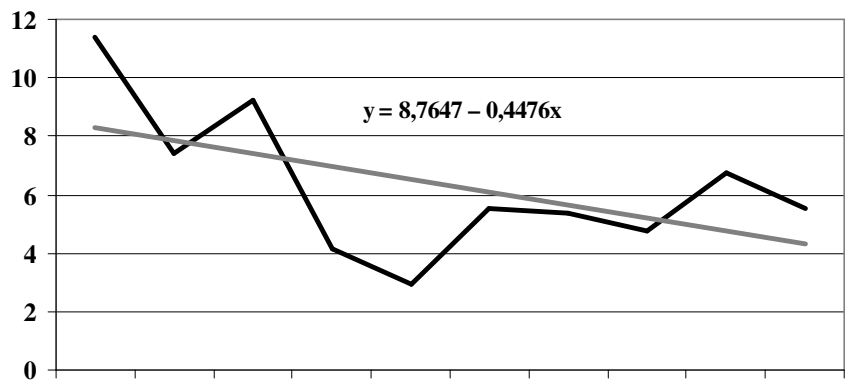

$\begin{array}{llllllllll}1998 & 1999 & 2000 & 2001 & 2002 & 2003 & 2004 & 2005 & 2006 & 2007\end{array}$

Source: own calculation

Figure 5. Yield average trend of the fruit plantation of Siófok between 1998 and 2007

Table 3. Characteristics of the plantation in Gyöngyös

\begin{tabular}{|l|c|}
\hline \multicolumn{1}{|c|}{ Type } & Elberta, Redhaven* \\
\hline Year of plantation & bitter almond \\
\hline Subject & Vase \\
\hline Crown shape & $5.5 * 3.5$ \\
\hline Row distance and distance between trees & 1.5 \\
\hline Size of plot (ha) & \\
\hline Soil quality (AK)33 & yes \\
\hline Irrigation & drip \\
\hline Method of irrigation & 3 cases / 10 years \\
\hline Frequency of frost damage & no \\
\hline Protection against frost & no cases / 10 years \\
\hline Frequency of frost damage & no \\
\hline Protection against frost & \\
\hline
\end{tabular}

Source: own compilation

Comment: * excellent frost tolerance 


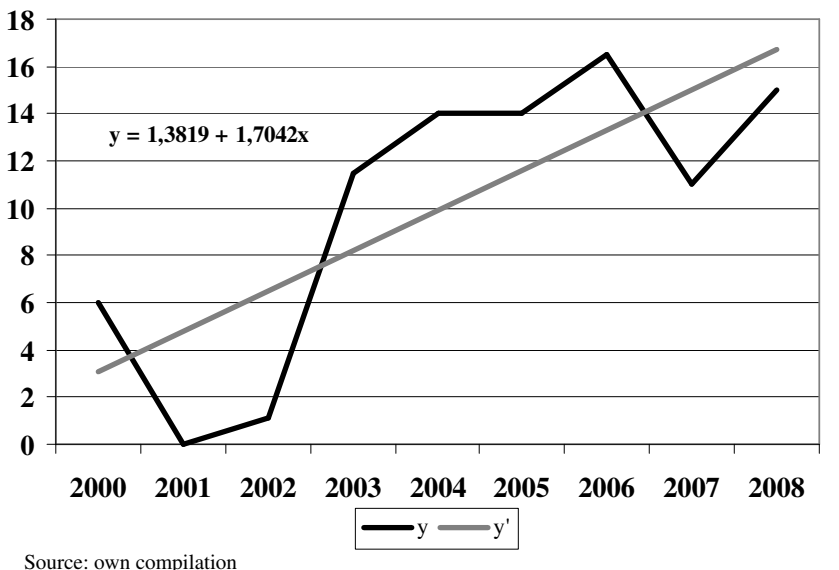

Figure 6. Yield average trend of the fruit plantation of Gyöngyös between 2000 and 2008

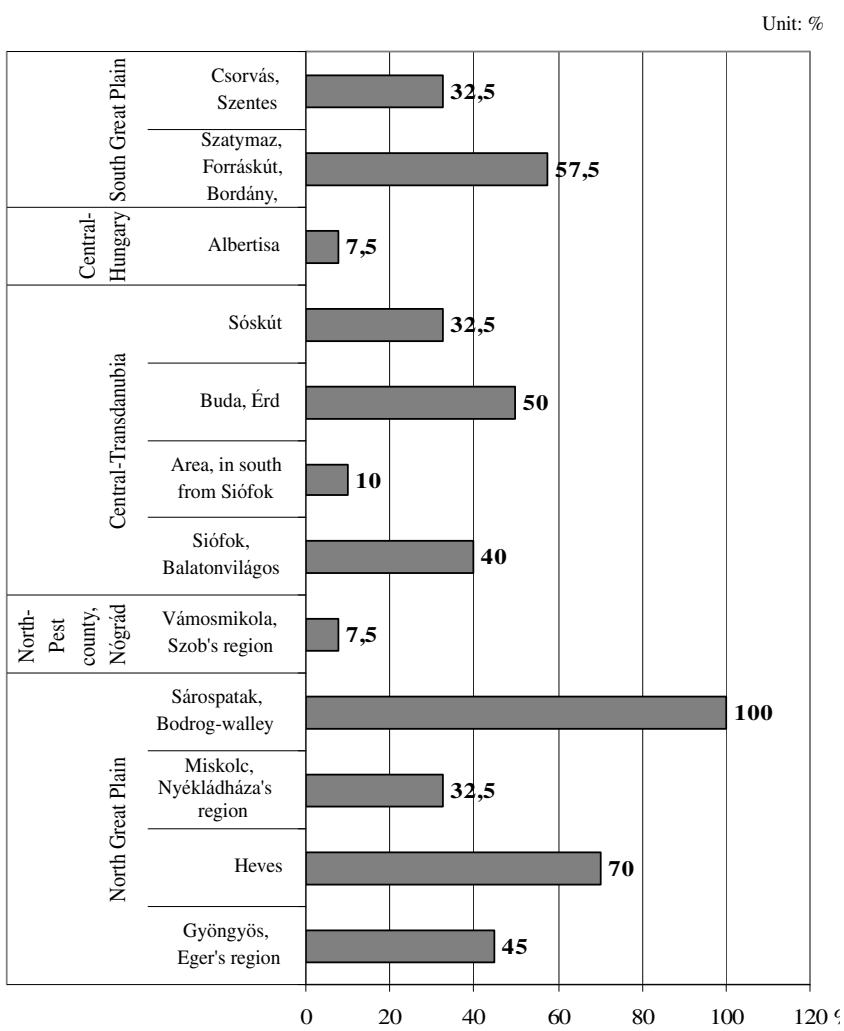

Source: Zöldség- és gyümölcspiac (Vegetable and fruit market), 2007

Figure 7. Frost damages affecting peach between 22-23 April, 2007 and 2-3 May

frost damages of 2007 can be seen in Figure 7. Frost did not occur in the middle part of the country (Northern-Pest county, Nógrád, Central-Hungary), damages were only $7.5 \%$. The most severe frost damage affected the NorthernPlain region, where the extent of frost reached $100 \%$-ot (Sárospatak, Bodrogvölgye).

Total yield loss occurred in the examined plantation due to frost damage in 2007 (Figure 8). Based on the provided database, production risk is calculated at $56 \%$ for 5 years, which is in accordance with the average of the cultivation area. The characteristics of the plantation are shown in Table 4.
Table 4. Characteristics of the plantation in Mezőnyárád

\begin{tabular}{|l|c|}
\hline \multicolumn{1}{|c|}{ Type } & $\begin{array}{c}\text { Redhaven*, Suncrest, } \\
\text { Elberta, Ford*, Red June } \\
\text { Champion*, Flavortop, } \\
\text { Incrochio Pieri* }\end{array}$ \\
\hline Year of plantation & 2000 \\
\hline Subject & wild autumn \\
\hline Crown shape & Vase \\
\hline Row distance and distance between trees & $6 * 4$ \\
\hline Size of plot (ha) & 5 \\
\hline Soil quality (AK) & $32-33$ \\
\hline Irrigation & yes \\
\hline Method of irrigation & drip \\
\hline Frequency of frost damage & no cases / 10 years \\
\hline Protection against frost & no \\
\hline Frequency of frost damage & 0 case / 10 years \\
\hline Protection against frost & \\
\hline
\end{tabular}

Source: own compilation

Comment: * excellent frost tolerance

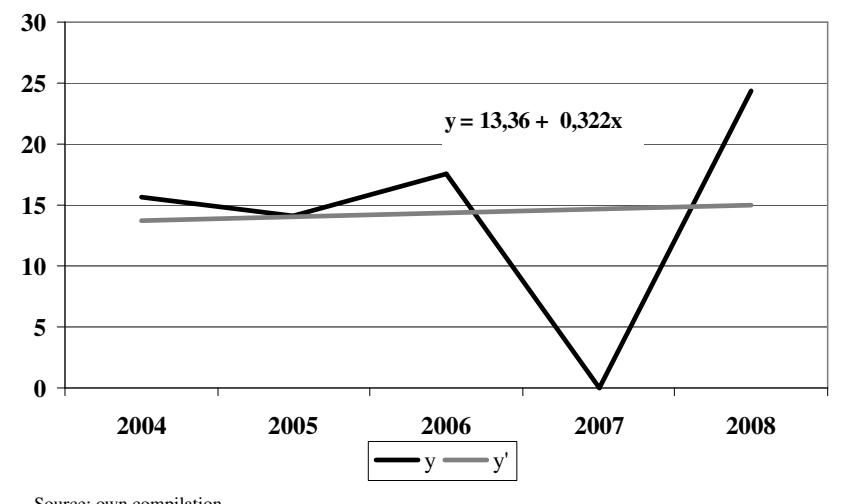

Figure 8. Yield average trend of the fruit plantation of Mezőnyárád between 2004 and 2008

\section{Summary}

Hungary possesses very favourable agroecological potential even in a European comparison. Fruit production has great traditions alongside plant production. Healthy nutrition requires high standards from fresh and processed vegetable and fruit products. The economic-social transformation characterising the change of regime severely affected both sectors. The efficiency of fruit production and especially production risk is determined by conditions of the cultivation site, this is especially true for sectors that are on the border of their productivity. Peach production in Hungary reached its peak in the 70s. Currently, we produce $50-60 \%$ of this quantity. Most of the production is concentrated on 5 cultivation sites, differing in size, production standard as well as in production risk. Peach is produced with relatively low risk on the largest cultivation site around Budapest and Pest county. On the other hand, peach is produced with high risks on large plantation areas integrated by fruit processors on sandy plains. It is apparent from different case studies that it 
is primarily the cultivation site that determines the risk of production in Hungary, but the age, modernity and cold tolerance of the used species also plays a role in this.

\section{Acknowledgements}

Herewith I would like to express our gratitude to Ertsey Imre, Nyéki József and Szabó Zoltán for the inspiration and assistance, and to the Research Projects: OTKA K63065/2006, OM-00042/2008, OM-00265/2008, OM$00270 / 2008$ for the subventions.

\section{References}

Ertsey, I. (1990): A kockázat mérésének módszertani kérdései a növénytermesztésben. Tisztántúli Mezőgazdasági Tudományos Napok előadás-kivonatai. Debrecen

Mohácsy, M., Maliga, P. \& Ifj. Mohácsy, M. (1959): Az őszibarack, (The peach) Mezőgazdasági Kiadó, Budapest, 397 p.
Molnár, T. (2007.): Egyszerüen statisztika, (Simply statistics) Perfekt Gazdasági Tanácsadó, Oktató és Kiadó Zártkörüen Működő Részvénytársaság, Kaposvár

Soltész, M. \& Holb, I. (2007): Integrált növényvédelem a csonthéjasok ültetvényeiben. (In: Nyéki, J., Soltész, M., Szabó, Z. (szerk.) Ökológiai szemléletü integrált gyümölcstermesztés (csonthéjasok).) Pixelgraf Bt. Kecskemét, 2007. pp. 58-69.

Szabó, Z. (1997): A kedvezőtlen meteorológiai hatások mérséklése. (Reducing unfavourable meteorological effects) 353-359 (In: Soltész M. (szerk.): Integrált gyümölcstermesztés.) Mezőgazda Kiadó, Budapest, 843 p.

Szabó, Z. (2004): Csonthéjas gyümölcsfajok fagytürése, (Frost tolerance of drupes) Debreceni Egyetem Agrártudományi Centrum, Habilitációs előadások

Szabó, Z. \& Nyéki J. (1988): Őszibarackfajták fagykárosodása (Frost damages of peach species). Gyümölcs-Inform, 1: 15-19 p.

Szücs, I. (2002.): Alkalmazott statisztika, (Applied statistics) Agroinform Kiadó

Timon, B. (2000): Őszibarack, (Peach) Mezőgazda Kiadó, Budapest 